\author{
Asian Journal of \\ Medical and Biological Research \\ ISSN 2411-4472 (Print) 2412-5571 (Online) \\ www.ebupress.com/journal/ajmbr
}

\title{
Article \\ Fish culture in net cages improves the livelihood of Charland population: a case study from Padma (Ganga) River, Munshiganj, Bangladesh
}

\author{
Tutul Kumar Saha, Jannatul Hosen and Zakir Hossain*
}

Department of Fisheries Biology and Genetics, Bangladesh Agricultural University, Mymensingh-2202, Bangladesh

*Corresponding author: Zakir Hossain, Department of Fisheries Biology and Genetics, Faculty of Fisheries, Bangladesh Agricultural University, Mymensingh-2202, Bangladesh. Phone: +8801724-939693; Fax: +8809161510; E-mail: zakir.fbg@bau.edu.bd

Received: 24 May 2021/Accepted: 25 June 2021/ Published: 30 June 2021

\begin{abstract}
Char dwellers are considered poorer than the mainland population. A constant threat of riverbank failure, flooding, and seasonal cyclone, combined with lack of physical infrastructures, and employment opportunities in the Chars, makes a vulnerable, difficult, and fragile life. The aim of the present work was an initiative to improve the livelihood of Char dwellers through fish culture in the net cages. A focus group survey was conducted on Char dwellers to know about the livelihood conditions. Quantitative and qualitative analysis of plankton was performed to know the productivity of the Padma River. In the study area, there was an average of 5 household members in each family of the Charland dwellers, and the average sex ratio of males and females was $56.67 \%$ and $43.33 \%$, respectively. The age group of below 15 to 60 years and their religion ratio of Muslim and Hindu was $45 \%$ and $55 \%$. The total number of identified genera of phytoplankton was 41 , and the total number of zooplankton genera was 20 in the Padma River. Tilapia (Oreochromis niloticus) was cultured in the net cages providing three different feeds i.e. natural feed, kitchen waste (leftover rice), and rice bran. The final weights of the experimental tilapia were $314.8 \pm 24.3 \mathrm{~g}$ after 5 months of feeding natural food, $321.4 \pm 22.8 \mathrm{~g}$ after 5 months of feeding natural food with kitchen waste, and $324.8 \pm 29.5 \mathrm{~g}$ after 5 months of feeding natural food with rice bran. Considering the plankton populations and water quality parameters, the Padma River near the Charland of Munshiganj was productive for fish farming. We found the results of Genetically Improved Farmed Tilapia (GIFT) farming in net cages near the river of Char, which were almost the same (has no significant difference among the diets) by providing low-cost supplementary feed and without supplementary feed. Therefore, the result indicates that Char dwellers can culture fishes in net cages to have the fish in their daily meals and can earn extra income from selling the fish to improve their livelihood. Moreover, applied research and interdisciplinary adaptive policy framework are requisite for the Charland livelihoods sustainability in the Padma River, Munshiganj, Bangladesh.
\end{abstract}

Keywords: socio-economic status; livelihood condition; char dwellers; net-cage culture

\section{Introduction}

In Bangladesh, more than 70 percent of Bangladesh's population and 77 percent of its labour force live in rural areas. About fifty percent of all of Bangladesh's workers and two-thirds in rural areas are directly employed by agriculture and farming, and about 87 percent of rural households engaged in agriculture for at least part of their income (IBRD.IDA, 2016). Since its independence in 1971, Bangladesh remained a low-income country with nearly 50 million people still living in poverty till 2015, it reached a lower-middle-income status in 2015 and was impacted by climate change (World Bank, 2021). Bangladesh's rural economy, and specifically agriculture, have been incredible drivers of poverty reduction in Bangladesh since 2000. Agriculture was accountable for $90 \%$ of the reduction in poverty between 2005 and 2010 (IBRD.IDA, 2016). 
Bangladesh is crisscrossed by 230 of the world's most unstable rivers (BWDA, 2019). Annually up to 20,00030,000 households lose their homes, land, and livelihood due to erosion by several mighty rivers in Bangladesh and thus become destitute (The New Humanitarian, 2019). These are the causes of monsoon rains (June October) and control of river's water by upstream countries. The process of erosion and accretion in the world's largest river delta is the major driver of poverty in "Chars". Chars in the river basins of the Padma, Jamuna, Brahmaputra, etc., are deprivation traps due to their geographical vulnerability and isolation (Sarker et al., 2003). In Bangladesh, approximately 600,000 people live on riverine islands and bars in Bangladesh, locally known as Char lands. They need to struggle into a trap of distress, destitution, and deprivation. Charland remains an underutilized national resource in Bangladesh within the overall socio-economic and political aspects (Barkat et al., 2007). Economic opportunities for poor and vulnerable char dwellers, who mainly depend on agriculture and livestock for their livelihoods, are narrow due to geographical isolation, weak markets, and effects of climatic hazards such as floods, and seasonal cyclones.

Rapid erosion of farmland makes many people landless, who then move to newly accreted land on emerging chars which have unfavorable conditions for agriculture due to sandy soil and frequent flood. These Charlands are extremely vulnerable to cyclones and storms; harsh living conditions due to lack of drinking water and fuel; and during the dry season (November - March), conversely, many char lands suffer from drought due to low water retention in silty/sandy soils. In these circumstances, char dwellers lend money with high interest to buy the fish net to catch the fish in the adjacent river (DFID, 2003). Since catches from the River are very poor, they can neither return the money to the lender nor run their family well. About 3,500 cages are in operation now in Chandpur along the Dakatia River, 500 cages in Laxmipur along the Meghna River. Altogether, these cages are producing at least 3,200 metric tons of tilapia annually (Baqui and Bhujel, 2011). There is utmost need to start such type of cage culture in char areas. So, suppose we can introduce fish culture in net cages to their adjacent productive river. In that case, char dwellers will get nutritious foods for their family and they can earn extra money to sell the produced fish with minimal effort. The objective of the study was to improve the livelihood conditions of the Char people by introducing net cages fish farming in the Padma River. Moreover, applied research and interdisciplinary adaptive policy framework are requisite for the Charland livelihoods sustainability in the Padma River, Munshiganj, Bangladesh.

\section{Materials and methods}

\subsection{Study area and periods}

The present study was conducted at chars of the Padma river of Louhajang Upazila, Munshiganj district, Bangladesh; located between $23^{\circ} 47^{\prime} \mathrm{N}, 90^{\circ} 37^{\prime} \mathrm{E}$ in latitude and longitudes, respectively (Figure 1). It is bounded by Dhaka and Narayanganj on the north; Madaripur and Shariatpur on the south; Comilla and Chandpur on the east; and Faridapur on the west. The study was conducted for a period from July 2018 to June 2020.

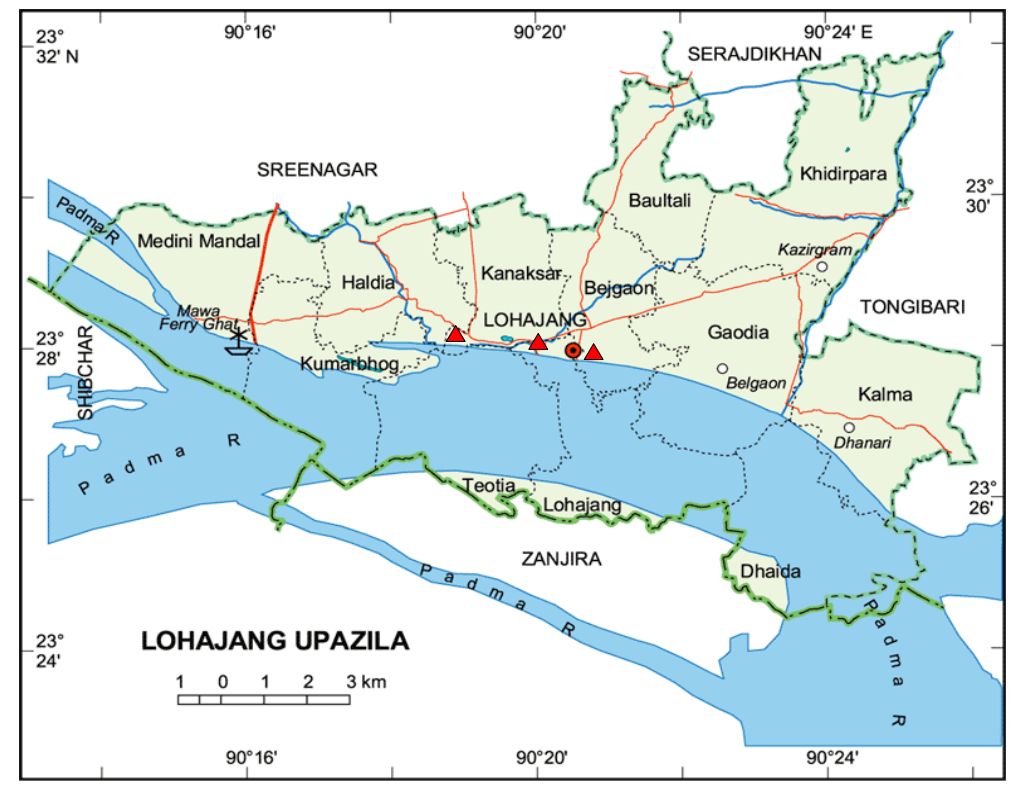

Figure 1. Map showing study areas adjacent to the Padma River; Lohajang, Munshiganj. 
2.2. Questionnaire development

The questionnaires were developed for household surveys in the study. The livelihood condition of the char dwellers considering their family income, educational level, medical facilities, were included to develop the questionnaire.

\subsection{Sample size}

In the present study, there were one hundred and twenty Charland dwellers interviewed from sixty households to observe the livelihood conditions of their families. However, the sample size was determined by using Kadam's formula (Kadam et al., 2010). Considering the resource limitation, we propose selecting samples for the questionnaire survey at $95 \%$ level of significance for 1 degree of freedom at 5\% desired probability level.

\subsection{Sampling strategy for questionnaire survey}

The socio-economic status and improvement of livelihood conditions from the Charland of Louhajang Upazilla under the Munshiganj district were collected for this study. The questionnaire was pre-tested using a sample group to assess the appropriateness of the questionnaire.

\subsection{Collection and identification of plankton samples}

Within the study periods, plankton samples were collected every month by using the plankton net (40 $\mu \mathrm{m}$ mesh size) from the Padma river at Munshiganj district in Bangladesh. Samples were collected through two methods those were horizontal tow (for surface towed) and vertical tow (for bottom towed). The surface water sample was collected through the method of horizontal towing. Where floaters were placed on the end of the ring and heavy material at another end of the ring. Volumes of water were collected through the net. The bottom water sample was collected through vertical tow as a ring at mouth of the net was heavy to dip deep into the water. The depth of the net was measured with the help of a plastic rope tied with a ring and marked with scales, which were used to calculate the amount of water.

Collected samples were preserved at 4\% neutral buffered formalin (Kapiris et al., 1997) in the plastic container. A light microscope (brand: The Micro Instrument Company; Model: Mi-ACST 41000000; magnification power: 10x-40x) was used to observe the sample and identify the species following the Sedgwick-Rafter (S-R) cell. Steinberg's (2011) method was followed in the process of identification. In the identification of zooplankton Abdullah's (2018) keys were followed. Plankton abundance is used as a bioindicator of the productivity of a water body (Hossain et al, 2020a).

\subsection{Quantification of plankton}

The Sedgwick-Rafter (S-R) (Steinberg et al., 2011) cell was used for counting phytoplankton, where the cell was $50 \mathrm{~mm}$ long, $20 \mathrm{~mm}$ wide, and $1 \mathrm{~mm}$ deep. To adjust the number of organisms per liter, a correction factor was multiplied with the number of cells per $\mathrm{mm}$.

\subsection{Training on fish culture in net cages}

A training program was arranged for 25 interested people living in the selected Charland of Louhajong Upazila near the village of Kanakshar. They were being trained about the preparation of net cages, advantages of fish culture in net cages, and the cost-benefit analysis of the fish culture technique. Among the trainee, approximately $90 \%$ of them adopted the program.

\subsection{Preparation of net cages}

Fishnet cages were prepared by using a few low-cost materials. Bamboo poles formed the outer frame covered by netting and floats (made from reused plastic bottles), and those were added at the corners to let the cages rise and fall in the water. Cages had a top cover to prevent fish from jumping and escaping or being caught by birds. The size of the cage was $3 \mathrm{~m} \times 2 \mathrm{~m} \times 1 \mathrm{~m}$.

\subsection{Stocking of fish in net cages}

Forty (40 individuals) monosex GIFT (Genetically Improved Farm Tilapia) were stocked in one fish cage (1 $\mathrm{m}^{3}$ ). Length and weight were recorded during stocking time. Fish was stocked for 4-6 months to attain the standard marketable size. A sampling of random ten fish was performed without lifting the cages in every month to measure the length and weight of the cultured fish. 
2.10. Feeding the fish

Three different types of feed were used for feeding the fish, i.e. natural feed from the river water, kitchen waste (leftover rice), and rice bran for five months. Three replications were maintained for each treatment group.

\subsection{Statistical analysis}

The data were analyzed by one-way analysis of variance (ANOVA) by using the SPSS software (v22.0). Data were presented as mean \pm standard error (SE). GIS software was used as an interface of MapInfo and digitized maps from ArcGIS (v10.5). Other statistical data were analyzed by using Microsoft office (v2010) and then presented as data form.

\section{Results}

\subsection{Demography}

In the present study, the primary livelihood information of Charland dwellers in Louhajang, Munshiganj region was observed (Table 1) and found that there were on average 5 household members of each Charland family. In the study area, the average male population $(56.67 \%)$ was relatively larger than the female population (43.33\%). In the fishers' community, the most active and working people belong to the age group of 15 to 60 years. Hindu (55\%) fishers were relatively dominant compared to the Muslim (45\%) religious community. A maximum number of the fishers were illiterate $(80.83 \%)$ and a small number $(12.5 \%)$ can put sign only. Most of the fisher community with a nuclear family $(60 \%)$ and the remaining had joint families $(40 \%)$. During the study period, a relatively higher number of fishers were permanently involved $(65 \%)$ with the fishing activity and others were seasonal or temporarily (35\%) involved.

In the fishers' community, each family had 3 children on average. The maximum (86.4\%) living houses were made with tin-shed materials where all the community people strongly depended on deep or semi-deep tube well (100\%) for the source of drinking water. Most of the fishers in the community practiced with semi-hygienic sanitation type $(92.40 \%)$, whereas the remaining (7.60\%) of fishers used unhygienic sanitation type. The permanent and temporary fishers in the Charland actively or passively spent an average of 12 hours for fishing activity.

\subsection{Water quality parameters}

The climate factors, especially the water quality parameters, are given in table 2 where different climate factors were recorded. The temperature, $\mathrm{pH}, \mathrm{DO}$ and salinity of water were recorded in the range of $(28.7 \pm 0.66){ }^{\circ} \mathrm{C}$ to $(32.3 \pm 0.52){ }^{\circ} \mathrm{C},(7.8 \pm 0.26)$ to $(8.9 \pm 0.41),(7.8 \pm 0.26) \mathrm{ppm}$ to $(8.9 \pm 0.41) \mathrm{ppm}$ and $(0.10 \pm 0.01) \%$ o to $(0.15$ $\pm 0.01) \%$, respectively in the Padma river. The climatic factors fluctuated in the river for different reasons including season, geographic location, environment, sampling time, and temperature of effluents entering the stream.

\subsection{Plankton community in the Padma river}

In the Padma River, a total of 41 phytoplankton genera were identified, and the whole identified genera of zooplankton were 20. The six groups of Bacillariophyceae, Chlorophyceae, Cyanophyceae, Euglenophyceae, Xanthophyceae, and Dinophyceae were included in phytoplankton community. Whereas the zooplankton community included four groups; Rotifera, Copepoda, Cladocera, and Ostracoda. In the Padma River, the peak level of phytoplankton was recorded in the group of Chlorophyceae having 15 genera, and the lowest level was in the group of Dinophyceae having one genus. Whereas in the zooplankton community, the highest was in the Rotifera having nine genera group, and the lowest level recorded in the group of Ostracoda having one genus (Table 3).

\subsection{Growth performance of GIFT Tilapia}

Genetically improved Farmed Tilapia (GIFT) was attained $314.8 \pm 24.3,321.4 \pm 22.8,324.8 \pm 29.5 \mathrm{~g}$ fed with natural food of the river, kitchen waste plus natural food, and rice bran plus natural food, respectively (Table 4). Three fish made one $\mathrm{kg}$ is an excellent marketable size for the consumers. GIFT tilapia was also attained $15.6 \pm$ $0.7,15.7 \pm 0.8$, and $15.2 \pm 1.1 \mathrm{~cm}$ fed with natural food of the river, kitchen waste plus natural food, and rice bran plus natural food, respectively (Table 5). 
Table 1. Basic information about the Charland dwellers in Louhaganj, Munshiganj (Ema et al., 2020).

\begin{tabular}{lll}
\hline Particulars & & Percentages of fishers (\%) \\
\hline Average household size (no.) & & 5.00 \\
\hline Average dependency ratio (no.) & & 2.13 \\
\hline \multirow{2}{*}{ Average sex distribution } & Male & 56.67 \\
& Female & 43.33 \\
\hline \multirow{2}{*}{ Average age } & Below15.00 years & 9.17 \\
& 15.01 to 30.00years & 32.50 \\
& 30.01 to 45.00years & 39.17 \\
\multirow{2}{*}{ Religion } & 45.01 to 60.00 years & 19.17 \\
\hline \multirow{2}{*}{ Marital status } & Islam & 45.00 \\
& Hindu & 55.00 \\
\hline \multirow{2}{*}{ Family type } & Unmarried & 19.17 \\
\hline \multirow{2}{*}{ Average children (no.) } & Married & 80.83 \\
\hline \multirow{2}{*}{ Literacy rate } & Nuclear family & 60.00 \\
& Joint family & 40.00 \\
\hline \multirow{2}{*}{ Occupational status } & Male & 1.70 \\
& Female & 1.30 \\
\hline \multirow{2}{*}{ Fishers type } & Illiterate & 70.83 \\
& Sign only & 12.50 \\
Housing condition & Primary and above & 6.67 \\
\hline \multirow{2}{*}{ Source of drinking water } & Fishing only (with licence) & 34.17 \\
& Fishing only (without licence) & 36.67 \\
\multirow{2}{*}{ Sanitation type } & Fishing and others & 39.17 \\
\hline Average fishing time (hr/day) & Permanent & 65.00 \\
& Temporary & 35.00 \\
\hline & Muddy house & 13.60 \\
& Tin-shed & 86.40 \\
\hline & Pond & 0.00 \\
& Own tube well & 46.00 \\
& Others tube well & 54.50 \\
\hline & Unhygienic & 7.60 \\
& Semi-hygienic & 92.40 \\
\hline
\end{tabular}

Table 2. Water quality parameters during the study period in the Padma River at Louhajang, Munshiganj (Hossain et al., 2020a).

\begin{tabular}{llll}
\hline Parameters & Pre-monsoon & Monsoon & Post-monsoon \\
\hline Temperatures & $32.3 \pm 0.52$ & $28.7 \pm 0.66$ & $30.4 \pm 0.65$ \\
Dissolved oxygen (DO) & $7.80 \pm 0.26$ & $8.90 \pm 0.41$ & $8.10 \pm 0.30$ \\
pH & $8.00 \pm 0.25$ & $8.20 \pm 0.15$ & $7.70 \pm 0.25$ \\
Salinity & $0.15 \pm 0.01$ & $0.10 \pm 0.01$ & $0.10 \pm 0.01$ \\
\hline
\end{tabular}

Table 3. List of plankton genera found from the Padma River during the study period.

\begin{tabular}{lll}
\hline Plankton & Group & Genera \\
\hline Phytoplankton & Bacillariophyceae & Melosira, Synedra, Coscinodiscus, Stephanodiscus, Diatoma, Navicula, \\
& & Rhizosolenia, Fragillari Cyclotella, Gyrosigma, Amphora, Rhizosolenia \\
& Chlorophyceae & Scenedesmus, Protococcus, Gonatogygon, Pediastrum, Spirogyra, Oocystis, \\
& & Hydrodictyon, Microspora, Closterium, Genecularia, Palmellococcus, \\
& Planktosphaeria, Pleodorina, Netrium, Zygnema & \\
& Cyanophyceae & Anabaena, Aphanizomenon, Aphanocapsa, Chroococcus, Merismopedium, \\
& Microcystis, Nostoc Polycistis, Spirulina \\
& Dinophyceae & Ceratium \\
& Euglenophyceae & Euglena, Phacus \\
& Xanthophyceae & Botrydium, Tribonema \\
\hline Zooplankton & Rotifers & Asplanchna, Filinia, Hexarthra, Brachionus, Trichocerca, Kellicottia, \\
& & Keratella, Gastropus, Polyarthra
\end{tabular}


Cladocera

Copepoda

Ostracoda
Daphnia, Bosmina, Diaphanosoma, Moina ,Sida

Calanoid, Cyclops, Diaptomus, Nauplius, Laptodora

Cypris

Table 4. Mean weight $(\mathrm{gm}) \pm$ SD of $O$. niloticus fed the natural food, kitchen waste and rice bran for 5 months.

\begin{tabular}{lllllll}
\hline Diets & \multicolumn{5}{c}{ Weight $(\mathbf{g m})$} \\
\cline { 2 - 7 } & Initial & 30 Days & 60 days & 90 days & 120 days & 150 days \\
\hline Natural feed $^{* \mathrm{NC}}$ & $5.5 \pm 0.9$ & $20.3 \pm 0.7$ & $70.4 \pm 7.6$ & $120.8 \pm 15.7$ & $202.2 \pm 26.8$ & $314.8 \pm 24.3$ \\
Kitchen $^{*}$ aste $^{\mathrm{NC}}$ & $5.6 \pm 0.7$ & $21.6 \pm 1.2$ & $86.8 \pm 7.7$ & $130.6 \pm 12.4$ & $210.5 \pm 20.0$ & $324.8 \pm 29.5$ \\
Rice bran $*^{\mathrm{NC}}$ & $5.5 \pm 0.8$ & $22.3 \pm 1.8$ & $88.4 \pm 6.7$ & $134.0 \pm 15.7$ & $225.0 \pm 17.5$ & $321.4 \pm 22.8$ \\
\hline
\end{tabular}

*NC; indicates Not Significance

Table 5. Mean length $(\mathrm{cm}) \pm$ SD of $O$. niloticus fed the natural food, kitchen waste and rice bran for 5 months.

\begin{tabular}{lllllll}
\hline Diets & \multicolumn{5}{c}{ Length $(\mathbf{c m})$} \\
\cline { 2 - 7 } & Initial & 30 Days & 60 days & 90 days & 120 days & 150 days \\
\hline Natural feed ${ }^{* \mathrm{NC}}$ & $6.5 \pm 1.0$ & $9.4 \pm 0.2$ & $11.4 \pm 1.1$ & $13.1 \pm 1.5$ & $13.8 \pm 1.4$ & $15.6 \pm 0.7$ \\
Kitchen waste ${ }^{\mathrm{NC}}$ & $6.6 \pm 0.5$ & $8.9 \pm 0.9$ & $11.8 \pm 1.1$ & $13.1 \pm 0.7$ & $14.6 \pm 0.8$ & $15.7 \pm 0.8$ \\
Rice bran ${ }^{\mathrm{NC}}$ & $6.5 \pm 0.9$ & $8.7 \pm 1.2$ & $10.7 \pm 0.9$ & $11.14 \pm 1.3$ & $13.4 \pm 0.9$ & $15.2 \pm 1.1$ \\
\hline
\end{tabular}

*NC; indicated Not Significance

\section{Discussion}

Human capital may be the most crucial livelihood resource for the char dwellers. It encompasses labour, income capacity, household relation, education status, types of occupation, etc. These parameters depend on the internal demographic factors of the family, such as gender, age, marital status, family size, etc. (Ellis, 2000). However, among the determinants mentioned above family size, earning source, education, and number of earning persons have purposively been selected to determine human capital in this study. It is found that the average family size was about 5, which was comparatively higher than the family size (4.59) at the District level (BBS, 2015). In the study area, the average sex ratio was 131 males per 100 females. Islam et al. (2020) found $76.67 \%$ male and $23.23 \%$ female in the Kishoregonj Haor region. The age group of below 15 to 60 years, which is considered as active and working group in the fishers' community and their religion ratio were Muslim $45 \%$ and Hindu $55 \%$. According to Shill et al. (2016), 80\% of fishers were Hindu in Munshiganj. But according to Islam et al. (2020), Muslims were dominant in the Haor region in Kishoreganj. Most of the fishers had a nuclear family (60\%), and few had joint family (40\%). During this study period, fishers were considered as permanent (65\%) and temporary (35\%) according to their fishing activity in each season. In the fishers' community, the average children number was 3. Most of the house was tin shed house (86.4\%), and the drinking water source was tube well (100\%). In Shill et al., (2016), most (58\%) of the houses were found Kacha near Padma river. Most of the fishers were used semi hygienic sanitation type (92.40\%), only $7.60 \%$ of fishers were used unhygienic sanitation. Rahaman et al. (2020) reported that 59\%. 13\%, 21\%, and 7\% of fishers used tin shed, semicemented, cemented, and open toilets at Chandpur and 52\%, 26\%, 16\%, and 6\% at the Patuakhali region.

The total number of identified genera of phytoplankton was 41 , and the total number of zooplankton genera was 20 in the Padma River. Phytoplankton was included in the six groups of Bacillariophyceae, Chlorophyceae, Cyanophyceae, Euglenophyceae, Xanthophyceae, Dinophyceae, while zooplankton included Rotifera, Copepoda, Cladocera, and Ostracoda. The highest and lowest numbers of phytoplankton were recorded from groups Chlorophyceae (15 genera) and Dinophyceae (one genus), whereas the number of zooplankton groups, Rotifera (nine genera) and Ostracoda (one genus), respectively in the Padma river. According to Monjurul and Pramanik (Monjurul et al., 2017), a total of 41 genera of 6 groups of phytoplankton and 31 genera of four zooplankton groups were identified in the Meghna river. According to Rakhi et al. (2013), a total of 20 and 17 genera of phytoplankton were recorded in Burignga and Turag river, respectively and 6 major zooplankton taxonomic groups were also identified during the monsoon in both river (Hossain et al., 2018). Additionally, Rahaman et al. (2019), a total of seven groups, including 41 genera, were of phytoplankton, and four groups, including 31 genera of zooplankton, were recorded in the Meghna River. The present diversified planktons indicated that the Padma River is a suitable habitat for fish. 
The production of tilapia in the net cages of the present study is consistent with the findings of Ahmed et al. (2014). They found the final weight of tilapia as $207.90-271.48 \mathrm{~g}$ at $50 / \mathrm{m}^{3}$ densities over 120 days rearing in suspended cages (Mollah et al., 1995). They fed the fish commercial feed (Jahan et al., 2020) supplemented with probiotics in the river of Dakatia, Chandpur, Bangladesh. Begum et al. (2017) also demonstrated the final weight (Mollah et al., 1997; 1998) of tilapia attained from 202.45 - 275.88 gm for 120 days reared in net cages supplied floating feed with probiotics at a pond of Sylhet Agricultural University (SAU). Bangladesh, which is comparatively lower than the findings of the present study.

\section{Conclusions}

A constant threat of riverbank erosion and flooding, combined with a lack of physical infrastructure, government services, and employment opportunities in the chars, makes for a vulnerable, complex, and fragile way of life are the challenges of char dwellers. Considering the plankton population and water quality parameters, the Padma River near the Charland of Kanakshar union of Louhajong upazila in Munshiganj is productive for fish. We found that culturing GIFT tilapia in net cages near the river of char with low-cost feed and without feed provides similar results. Therefore, it indicated that char dwellers could culture the fish in net cages to get the fish in their meal and could get extra income selling the fish.

\section{Acknowledgments}

The authors are thankful to the Planning Division, Social Science Research Council, Ministry of Planning, Shere-Bangla Nagar, and Dhaka for providing funds for the research work under a project.

\section{Conflict of interest}

None to declare.

\section{Authors' contributions}

TKS has collected the data, analyzed the data and wrote this manuscript. JH has collected the data, analyzed and wrote this manuscript. ZH critically supervised and helped in manuscript finalization. All authors have read and agreed to the published version of the manuscript.

\section{References}

Abdullah AM, MD Alam and A Akhtar, 2018. Annual pattern of zooplankton communities and their environmental response in a subtropical maritime channel system in the northern Bay of Bengal, Bangladesh. Acta Oceanol. Sin., 37: 65-73.

Ahmed T, SJ Hasan, MRA Hossain, I Haidar, AKMSA Rubel and MH Pramanik, 2014. Assessment on impact of dietary probiotic supplementation on growth indices of monosex tilapia (Oreochromis niloticus) cage culture at Dhakatia River, Chandpur, Bangladesh. World J. Fish Mar. Sci., 6: 441-446.

Barkar A, 2007. Charland in Bangladesh: Political Economy of Ignored Resource. Pathak Shamabesh, Dhaka, Bangladesh. 105-107 pp.

Barkat A, KR Prosanta and MS Khan, 2007. Charland in Bangladesh: Political Economy of Ignored Resource, Pathak Shamabesh, Dhaka, Bangladesh.

BBS, 2015. Bangladesh population and housing census 2011 zila report: Chapai Nawabganj Statistics and Informatics Division, Ministry of Planning Government of the People's Republic of Bangladesh. 54 pp.

Begum N, MS Islam, AKMF Tlaque and IN Suravi, 2017. Growth and yield of monosex tilapia (Oreochromis niloticus) in floating cages fed commercial diet supplemented with probiotics in freshwater pond, Sylhet. Bangladesh. J. Zool., 45: 27-36.

Bhouyain AM and GSM Asmat, 1992. Freshwater zooplankton from Bangladesh. Gazi Publishers, Dhaka, Bangladesh. 32-15pp.

BWDA, 2019. Bangladesh Water development board. Available: https://www.bwdb.gov.bd/.

DFID, 2003. Livelihoods in coastal fishing communities, and the marine fish marketing system of Bangladesh. Available: http://projects.nri.org/fishtrade/issues-marketcredit.pdf.

Ellis F, 2000. Rural livelihoods and diversity in developing countries. Oxford University Press, United Kingdom.

Ema NS, MS Hossain, MN Uddin, MM Rahman and Z Hossain, 2020. Study of the climate change impact on fishers' livelihood near the Padma river in Munshiganj, Bangladesh. Asian J. Med. Biol. Res., 6: 777-784.

Hossain MJ, MJ Sarker, MN Uddin, A Islam, IJ Tumpa and Z Hossain, 2018. Macrobenthos presence in the Estuarine waters of the Meghna River, Ramghati, Laksmipur, Bangladesh. World Appl. Sci. J., 36: 598-604. 
Hossain MS, MN Uddin, MM Rahman and Z Hossain, 2020a. Present status of fish and plankton biodiversity at the Padma River in Munshiganj district, Bangladesh. World Appl. Sci. J., 38: 386-394.

Hossain MS, MN Uddin, NS Ema, MM Rahman and Z Hossain, 2020b. Assessment of the fish and plankton biodiversity in the Bay of Bengal, Cox's Bazar, Bangladesh. World Appl. Sci. J., 138: 471-478.

IBRD.IDA, 2016. Bangladesh: Growing the Economy through Advances in Agriculture. Available: https://www.worldbank.org/en/results/2016/10/07/bangladesh-growing-economy-through-advances-inagriculture.

Islam A, MS Hossain and Z Hossain, 2020. Impacts of climate change on fishers' livelihood in Kishoregonj Haor region, Bangladesh. Asian J. Med. Biol. Res., 6: 408-417.

Jahan H, NS Ema, MS Hossain, MA Pervin, R Akter and Z Hossain, 2020. Growth performance study of silver barb (Barbonymus gonionotus) by replacing fishmeal with soybean meal in the diet. Asian J. Med. Biol. Res., 6: 149-154.

Kadam P and S Bhalerao, 2010. Sample size calculation. Int. J. Ayurveda Res., 1: 55-57.

Kapiris K, M Helen and Moraitou MA, 1997. Effects of formaldeyde preservation on biometrical characters, biomass and biochemical composition of Acartia clausi (Copepoda, Calanoida). Helgolaender Meeresuntersuchungen, 15: 95-106.

Kelly C and MHK Chowdhury, 2002. Integration of animal husbandry into home and the environment in Bangladesh: a quantitative and gardening programs to increase vitamin A intake from foods: qualitative assessment of causal linkages. Prepared for Bangladesh, Cambodia and Nepal. Asia Pacific Special DFTD, Government of UK, Dhaka. 32 pp.

Mollah MFA and Z Hossain, 1995. Growth and survival of African catfish (Clarias gariepinus) Burchell fry reared in cages at different stocking densities. Bangladesh J. Zool. 23: 179-182.

Mollah MFA and Z Hossain, 1997. Effects of different feeds on growth and survival of African Catfish (Clarias gariepinus) larvae. Bangladesh J. Agril. sci. 24: 13-17.

Mollah MFA and Z Hossain, 1998. Stocking density effects on growth and survival of African catfish (Clarias gariepinus) fry in net cages. Bangladesh J. Agril. sci. 25: 5-9.

Monjurul MM and MMH Pramanik, 2017. Fish biodiversity and their present conservation status in the Meghna river of Bangladesh. Int. J. Fish. Aquat. Sci., 5: 446-455.

Rahaman MJ, MS Hossain, MM Rahman and Z Hossain, 2020. Impacts of climate change on livelihood of the fishers at the Meghna, Laukhati and Galachipariver in Bangladesh. Asian J. Med. Biol. Res., 6: 81-92.

Rahaman MJ, NS Ema, MS Hossain, MM Rahman and Z Hossain, 2019. Effects of climate change on fisheries biodiversity of the Meghna, Laukhati and Galachipa River in Bangladesh. Eurasia J. Biosci., 13: 1705-1717.

Rahman MA and MM Rahman, 2012. Char formation process and livelihood characteristics of Char dwellers of Alluvial River in Bangladesh, 27 August-31 August 2012, Paris, France. 32pp.

Rakhi SF, AHMM Reza, MS Hossen and Z Hossain, 2013. Alterations in histopathological features and brain acetylcholinesterase activity in stinging catfish Heteropneustes fossilis exposed to polluted river water. Int. J. Aquatic Res., 5: 2-18.

Sarker MH, I Haque, M Alam and R Koudstaal, 2003. Rivers, chars and char dwellers of Bangladesh. Int. J. River Basin Manage., 1: 61-80.

Sarker MH, I Huque, M Alam and R Koudstaal, 2003. Rivers, chars and char dwellers of Bangladesh. Int. J. River Basin Manag., 1: 61-80.

Sarker MNI, MA Ali and MS Islam, 2015. Causes and possible solutions of poverty perceived by char dwellers in Bangladesh. Int. J. Nat. Soc. Sci., 2: 37-41.

Sarker MNI, MA Kashem and MZ Rahman, 2007. Poverty alleviation of rural people through chars livelihoods program. J. Bangladesh Soc. Agril. Sci. Technol., 4: 203-208.

Shill S, A Sarker, M Asaduzzaman, GA Latifa, SC Podder and MA Obaida, 2016. Livelihood status of fishers of the Padma River, Sreenagar, Munshiganj. Bangladesh J. Zool., 44: 41-50.

Steinberg MF, LE Matthew, Drake LN, Bruce KD, Anderson DW and Nicholas HP, 2011. Comparison of techniques used to count single-celled viable phytoplankton. J. Appl. Phycol., 24: 1-8.

The New Humanitarian, 2019. Bangladesh's disappearing river lands. Available: https://www.thenewhumanitarian.org/Bangladesh-river-erosion-engulfs-homes-climate-change-migration.

World Bank, 2021. The World Bank in Bangladesh overview. Available: https://www.worldbank.org/en/country/bangladesh/overview. 